University of Louisville

ThinkIR: The University of Louisville's Institutional Repository

Electronic Theses and Dissertations

1939

\title{
The morphogenesis of the pectoral girdle of Amblystoma microstomum.
}

Raymond W. Lawrence

University of Louisville

Follow this and additional works at: https://ir.library.louisville.edu/etd

Part of the Animal Sciences Commons

\section{Recommended Citation}

Lawrence, Raymond W., "The morphogenesis of the pectoral girdle of Amblystoma microstomum." (1939). Electronic Theses and Dissertations. Paper 1827.

https://doi.org/10.18297/etd/1827

This Master's Thesis is brought to you for free and open access by ThinkIR: The University of Louisville's Institutional Repository. It has been accepted for inclusion in Electronic Theses and Dissertations by an authorized administrator of ThinkIR: The University of Louisville's Institutional Repository. This title appears here courtesy of the author, who has retained all other copyrights. For more information, please contact thinkir@louisville.edu. 


\title{
University of Loulsvilie \\ The Morphogenes1s of the Poctoral airdle \\ of Amblystoma Miorostomum
}

\author{
A Dissertation \\ Submitted to the Faculty of the \\ Graduate School of the UnIversity of Loulsville
}

\author{
In Partial Fulfiliment of the \\ Requirement for the Degree \\ of Master of sclence
}

Department of $\mathrm{BlOlog}$

By

Raymond W. Lawrence 
Name of Student: Rermond He Lawrence

T1tlo of Thes18: The Morohogeneste of the Pectorsl Alrdie of Amblyatoma M10rostomum

The 81: Director: Dr, H. B, Levell

Approved by a Reading Committee Composed of the Following:

Date: Mar 


\section{Acknowledgments}

To Dr. H. B. Lovell, whose stimulating guldanoe has boen a conatant source of inspiration and encouragement, and whose unt1ring efforts have made this work posalble, I exprese my alncere appreciation and grat1tude.

I also wish to thank Dr. P. A. Davies for his helpful criticlam and for his kindness in extending to me the facilities of the Dopartment of $\mathrm{Blology}$. 
CONTENTS

Page

I. Introduction ................ 1

II. Materials and Kothods ...., .... 7

III. Hormal Anatomy of the Pectoral a1rale 10

IV. Experimental Result:

A. Ext1rpat1ons ............. 14

B. Grafts................. 24

V. Ceneral D1scussion ........... 35

VI. Summary . . . . . . . . . . . 43

VII. I1terature c1ted . . . . . . . . . 44

VIII. PIgures .. . . . . . . . . . . 47 


\section{INTRODUCTION}

Early experiments upon the structure of the shoulder-girdle of salamanders, as cited by Swett (129 b), were made by Tornier (106) who showed that a small portion of the shouldergirale of Triton $\mathbf{w 1 1}$ regenerate a complete girdie, including the free 11mb. Fritsch (III)

and Kurz (12) substantlated these findings, according to swett. They demonstrated that regeneration follows after complete removal of the free limb and shoulder-girdle in Triton. Some of the earliest experiments on the 11mb anlage of Amblyatoma were made by Harrison (18). He found that there was a clrcular disc, three and one-helf somites in diameter, in the embryo which contalned almoat all the cells of 1imb-forming potency. H1s results demonstrated that the froe $11 \mathrm{mb} 1 \mathrm{~s}$ an equipotential reatitution syatem.

Detw11er (118) on the other hand found that parts of the girdie rudiment of $A$. punctatum are already determined at the stage when the $11 \mathrm{mb}$ rudiment 18 present as a definite thickening of 
the somatopleure (at the tall-bud stage). He reported that removal of a definite portion of the rudiment brings about a defect in that portion of the girdle corresponding to the part removed; that 1s, the peotoral girdle according to Detw1ler's reaults is a mosalo rather than an equipotential system.

The location of the free limb itself within the disc was determined by swott (123), who grafted portions of the limb bud which had been previously stained with a vital stain.

swett (129 a), using well-developed, activelyfeeding larvas of A. punctatum, found that girdles transplanted to orthotopic positions underwent some degree of s1ze reduction, probably because of the interruption of the supply of nourishment avallable for their malntenance and growth. In all orthotopic series a normal freo l1mb regenerated, 1rrespective of the normality of the girdle with which 1t articulated. Heterotopio transplantations were made by removing the girdle and placing it on the flank of the same animal. These transplants showed a marked degree of resorption. The speed of the resorption process was not dependent upon the length of time the 
animal was permitted to live after recelving the graft. First, the girdle became reduced over the ent1re surface; later, the more outlylng portion d1sappeared more rapidly, the soepula usually romalning the longest. Only two of these grafts produced free limbs, these $11 \mathrm{mb}$ boing small and Irregular.

The results of Swott and Parsons (129) appear to be contradictory to those of Detwiler, for they demonstrated that the cartilaginous shoulder girdle of Amblystome $w 111$ regenerate after 1ts complete removal in older stages. They used A. punetatum larvae ranging from 15 to $40 \mathrm{milll}$ meters. Serles of operations included: (1) removal of the girale and the free limb, (2) removal of the whole girdie leaving the free limb Intact, and (3) removal of the girdle and humerus. The regeneration of the shoulder girdles in all three types of experiments was essentially complete. The process began by a condensation of cella in the girdle region and was quite similar to the ombryological process which resulted in the production of the original girdle. Deficiencies were found largely in the most outlying parts of the girdle, chiefly in the suprascapula and 
procoracold.

Parsons (129) has reported that the shoulderg1rdle of A. punctatum w11l regenerate in a heterotopie position. The regeneration of the girdie took plece in the presence or in the absence of the froe 11mb. The $11 \mathrm{mb}$ also regenerated when removed. These transplants were from the right shoulder to the right Plank and were of nomal orientetion. 01rdies which developed from these grafts wore removed under ohloretone anesthesia when the animals had been fod from two to seventyfive days. The larvae were then returned to water and fod dally for perlods varjing from forty to sixty-one days, at which time relatively complete restitution of the girdles had taken place.

Swett (129 b) uaing A. punctatum larve which had just begun to foed reported that partial removal of the cartilaginous girdle was followed by it oomplete regeneration.

The comblned experiments of swett and Parsons show that in older stages the pectoral girdle behavea more $11 k$ an equipotential systom than mosa1c.

Stultz (136) has shown that the polvio girdle of A. punctatum 18 an equipotential system. When the hind-11mb rudiment was extirpated, the regener- 
ation of a complete free l1mb wa accompanied by the regeneration of a normal girale. In both the orthotopic and noterotoplc transplants, in whlch an extremity regenerates, topographlcally complete girdie results. In all his experiments both $11 \mathrm{mb}$ and girdie ruaiment possessed regulatory ablilty and are regarded as self-different1ating, equipotential systens.

Why should not the poctoral girdie be like the pelvie girdie in this respect, since they are belleved to be serially homologous? If the pectoral girdle 1s equipotential, any part or parts of the embryonic rudiment should produce a complete Girdlo, whereas if the 11 mb enlage is a mosalc one, number of centers of dovelopment should be present.

To compare A. mierostomum with A. punctatum, an attempt was made to tranoplant halves of the limb bud in a heterotopio, homopleural location. It was at first hoped that by feeding the animals for a longer period of time than had been done by Detwller, a more complete girdle would be obtalned.

1. Although the name Amblystoma mlerostomum has been replaced by amblystome texanum by the systematists, the former name 1s st111 used by morpholog1sts. 
Th1s, however, did not occur. In order to determine whether the pectoral girdle is an equipotential or a mosalc aystem, specific portions of the $11 \mathrm{mb}$ disc were extirpated and these portions transplanted to the flank of the anlmal. The rudimentary girdies whlch resulted have been studied both in the presence and absence of the free $11 \mathrm{mb}$ in order to determine the relationshlp, if any, between these two structures. As w111 be shown in the body of this paper, the findings in these experiments upon A. microstomum egree very closely with the results of Detwiler (118) upon A, punatatum. The present results show conclusively that the pectoral girdie of the former species is also a mosale of at least four primordia. When any of these primordia were extirpated, corresponding defect occurred in the girdle, and when any of these rudiments were transplanted to a heterotopic location, only the actual rudiments included in the grafted tissue appeared in the transplant. An attempt 111 be made to explain the discrepancies between the present results and those of swett and Parsons (129) upon the beses of the difference in age of the larvee at the time the experiments were performed. 
II. MATERIALS AND METHODS

Operations were performed at Harrison's stages 31-35 on embryos of Amblystome microstomum obtained in ponds in the vicinity of Loulsvilio, Kentucky.

The degree of development of the embryo has been Indicated by the use of Harrison's (unpublished) numbered stages. A camera-luolda draw1ng of stage 31 1s shown in figure 1. The somatopleure ventral to the pronephros has thickened, but there is as yet no appearance of the limb bud externally. During the next two stages the ta11 bud lengthons and the mesenohymal tissue in the limb bud region has gradualiy increased, making the $11 \mathrm{mb}$ bud a distinct rudiment. At stage 46 the animal begins to feed; the fore limbs have reached the three digit stage, and the hind $11 \mathrm{mb}$ buds are visible. Subsequent development 1 s designated by the number of days after the operation or by the total length of the larva.

The operations on some of the older animals 
were carried out under chloretone anesthesial. The erfect of the aneathesia wore off rapidiy as soon as the animels were returned to water and no 111 effects were observable.

D1ssection was done under the binocular mlcroscope. All operations were performed on the right sides of the animals (homopleural). A wound was made about three somites posterior to the normal $11 \mathrm{mb}$-bud to recelve the exc1sed portion of the $11 \mathrm{mb}$ anlage. Desired portions of the rudiment were exc1sed with finely sharpened 1rredectony sc18sors. Th1s portion of the girdle anlage was superimposed over the exposed mesoderm and was placed in normal orientation (fig. 1, p. 13). The grafts were pressed flrmly in place by a small glass straddle weight. The weight was romoved in about an hour, at whloh time healing had occurred. All wounde were oleaned of 10080 mesoderm in order to Insure the removal of all that portion of the Girdle anlage. The animals were kept in tap water, only one animal to a finger bowl. They were fed on small worms (Enchytraeus) unt1l they were about elght woeks old. Observations and sketches of

1. Chloretone anesthet1c was made by dissolving

$1 \mathrm{gm}$. chloretone in $3,000 \mathrm{cc}$. of .04 percent $\mathrm{NaCl}$. 
developing buds were made at frequent intervals. All the larvae were killed and fixed in a saturated solution of corrosive sublimate and five percent glecial acetic acid. Typical animals from each series were made into serial sections and studied histologically. Other experimental animals intended for whole mount were atalned in toto with a solution of one-half of one percent methylene blue dissolved in seventy-five percent alcohol. The solution stained the cartilages a falnt blue, whereas the surrounding musclo t1ssue absorbed 11ttle or none of the color. The cartilages were dissected out and examined with the dissecting microscope.

An area, larger than 1s occupled by the girdle and which contained the girdle, was ext1rpated from the animal. T1seues wh1ch surrounded the girdle could now be easily removed with teasing neodles.

Camera-lucida drawlings were made of the grafted limb bud just after killing, of the serlel sections, and of girdies taken from the whole mounts that had been stained with methylene blue. These girdles were stored in glycerine which allowed them to retain their color and kept them from deterlorating. 
III. NORMAL ANATOIY OF THE PECTORAL GIRDLE

Each half of the shoulder-girdle of A. microstomm may be regarded as singlo skelotal eloment which 1: incompletely divided into three reglons, rather than as an aggrogate of three fused segregates (F1g. 2, p. 13). The major portion of this arciferal girdle remalns cartilaginous, becoming oselfled only in the region of the glenold cavity. The peotoral girdle of salamandre maculosa has been described by Francis $(134)$ and a comparat1ve account of the pectoral girdle in Amblystome has been given by Noble (131).

The coracold is by far the largest portion of the pectoral girdle. It extends mesially from the glenold cavity across nearly two-thirds the widh of the body, so that the right side overlaps the left s1de. However, in one instance the left side was found to overlap the right side. These overlapping portions 110 immediately ventral to the heart, serving as protection for 1t. The coracold formo doop, conceve, cartilaginous plate with 1ts convex aurface ventral. Only a small part of the coracold in the region of the glenold cavity becomes 
ossifled. The peripheral freo edges are exceedingly thin. The coracold forms a faceted lip to the posterior border of the glenold cavity.

The procoracold forms the enterior portion of the vontral plate of the pectoral girdle. It is spatulate in shape and slightly ourved with the convexity on the ventral side. The proooracold is imperfectly demarcated from the coracold by deep notch, the 1nciaure corecoldes which separates the cartilaginous portions of the two regions. It also 18 ossified in the region of the glenold cavity, but romains cortilaginous anterlorly. This ossirication Is continuous with that of the coracold except for the foramen supracoracoldeum through which passes the I. supracoreceldidene and the corresponding artery and veln. A line dram from the glenold cevity through this foramen to the center of the Inciaure corecolden represents the boundary between the procoracold and coracold. The procoracold projects a consplouous 11p over the anterior face of the glenold cavity which forma definite facet to the head of the humerus. Thus the glenold cavity Is formed by lips of the coracoid and procoracold. The scapula reglons form the dor solateral portion of the pectoral girdle. The scapula proper 
1s completely ossified, whereas the distal portion of the scapula region comprises the suprascapula which 1s entirely cartilaginous. The whole structure 18 fan-shaped and so curved that the oonvexity 18 outwards. The scapula is elliptical in seotion and expands alightly toward its distal border, where it merges Into the suprascapula. The suprascapula extends Into a brosd fan, bolng thick at 1ts ventral border but thinning out dorsally. 


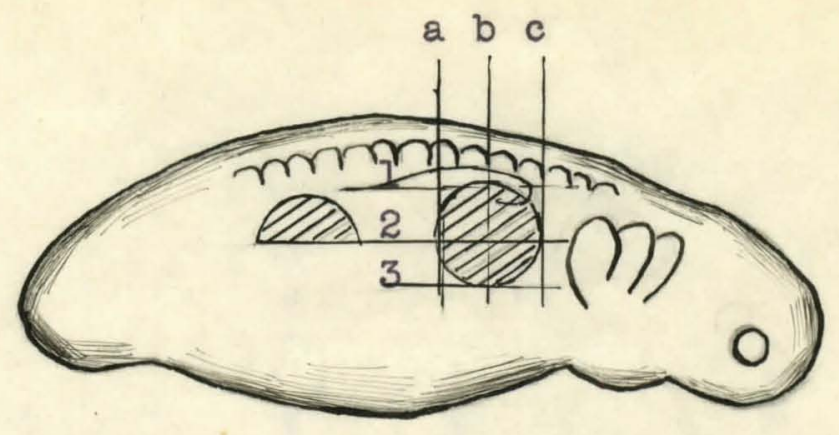

Fig. 1. Camera-lucida drawing of an embryo of $\underline{A}$. microstomum in the tail-bud stage showing areas of extirpations and locations of transplants.

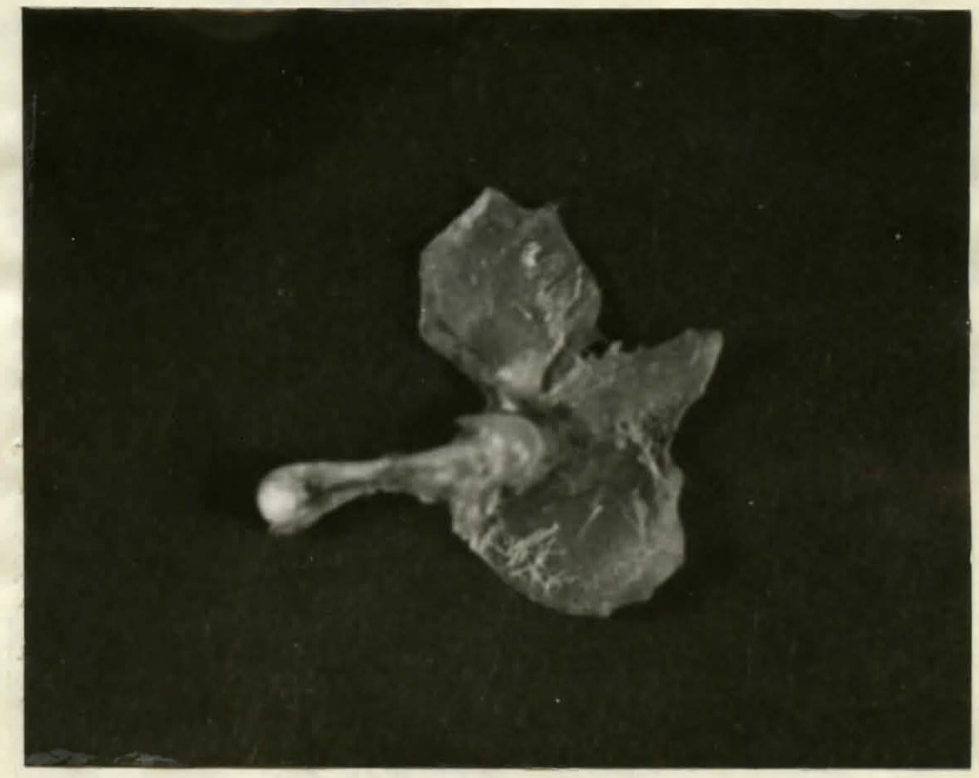

Fig. 2. Right half of the pectoral girale viewed from the ventrolateral aspect. Adult $\underline{A}$. microstomum. 
IV. EXPERIMENTAL RESULTS

\section{A. Ext1rpations}

1. Romorel of the dorgal half of the core$11 \mathrm{mb}$ mudiment (Series $\frac{1}{8} \mathrm{DE}$ ). The aymbols $\mathrm{DE}, \mathrm{VE}$, $P E$, and $A E$ have been used to designate the four serios of extirpation experiments, the first letters referring to the dorsal half, rentral half, posterlor half, and anterior half of the $11 \mathrm{mb}$ bud reopectively, and $\mathrm{E}$, the second letter, indicating ext1rpation. In the serles of transplants which have been designated by the symbols $D Q, V Q, P Q$, and $A G$, the first letters again refer to the portion of the $11 \mathrm{mb}$ bud removed, and the a indicater graft. Individual animals in each series have been numbered from 1-10. These ext1rpation experiments conslsted of the removal of the halves of the fore-l1mb bud as shown in figure 1. The dorsal half contalned the area a-c $\times 1-2$. In each case a wound was made on the elank of the animal to recelve the exclsed portion of the limb ruaiment. A further discusaion of this phase of the experiment w111 be taken up in 
connection with the development of the grafted 11mbs. In order to 1nclude all the 11mb-forming t1ssue, the exc1sed dorsal half of the limb bud Ineluded also the rudiment of the pronephros. All wounds were cleaned of loose mesoderm cells and in most cases were completely horled within twentyfour hours. The wounds were not covered. Thirty percent of these experiments regenerated complete limbs (tablo I). In this serles complete girdles were obtained with the presence of a regenerated 11mb. In case $\frac{1}{2}$ DE 1 each portion of the regenerated girdie (f1g. 3 A) is somewhat larger than the corresponding parts of the normal with but one exception, that being the glenold portion, which is slightly smaller than the normal. On the other hand a regenerated girdle obtained in the absence of the free $11 \mathrm{mb}$ was not complete. This girdle was represented in threo separate parts (fIg. 4 A). The suprascapula 1s apparently complete, but remains separate from the other girdle parts. The anteroposterior length of the suprescapula ia 360 microns as compared to 400 microns of the normal. There are two parta to the ventral portion of the glrdie. The procoracold and coracold are rudimentary and are not joined at any place 
Table 1

Showing reeults of ext1rpation

\begin{tabular}{|c|c|c|c|c|}
\hline Sertes & $\begin{array}{l}\text { Total } \\
\text { exp. }\end{array}$ & Lived & Regen. & $\begin{array}{l}\text { Not } \\
\text { Regen. }\end{array}$ \\
\hline$D \mathrm{DE}$ & 10 & 9 & 3 & 6 \\
\hline VE & 10 & 9 & 8 & 1 \\
\hline 글 $P E$ & 10 & 7 & 2 & 5 \\
\hline $\mathrm{AB}$ & 6 & 4 & 3 & 1 \\
\hline
\end{tabular}


w1th each other or with the suprascepula. The scapula and glenold fossa are completely missing. Results of four additional cases studied in this series agree in general with the above conclusions. Animals that falled to regenerate a free $11 \mathrm{mb}$ elso possessed an incomplete girdle, the central zone being absent, whereas in cases In which the limb regenerated; an apparently complete girdie was present. It is evident, therefore, that when both girdle and $11 \mathrm{mb}$ regenerate, the girdle is normal in size and archltecture as hown by comparison with the normal girdie. The presence of the supraseapuia in all cases Indicates that the primordium of this cartilage wa located more dorsally than the limb also exclsod. It would be necessary to ext1rpate the area dorsal to the limb bud in order to romove the primordium of the scapula.

2. Remeral of the rentral half of the core$11 \mathrm{mb}$ rudiment (Series tVE). The ventral half consisted of the area a-0 $\times 2-3$ (Fig. 1). Wounds were cleaned of 10080 mesoderm and left uncovered. Elghty percent of this serles regenerated apparentiy normal limbs. In two cases not only was normal I1mb regenerated, but the grafted t1ssue developed 
Into a palr of 11mbs. These wero mirror Images of each other. The humerl were ankylosed at their proximal ond and articulated in a singlo glenold foser, this fossa constituting the major portion of the grafted girdie (fig. $5 \mathrm{C}$ ). Here again in this seriea an orthotopie glrdle with a regenerated free limb shows a more complete structure than an orthotopic girdle having no attachment with a free limb (f1gs. 5-6). The essentially com-

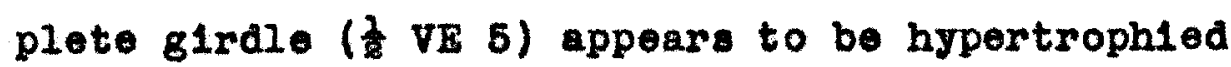
as compared to the normal.

Comparing the orthotopic girdle in cases in whlch a freo limb regenerated also with the normal, a completely regenerated glrdie is exhiblted (Plg. 5). Anteroposterior lengths of the normal and regenerated girdles are comparatively 1dentical as shown in table 2.

Each portion of the regenerated girdle, w1th the exception of the suprascapula, is alightly larger than the normal; restitution has been accompanfed by a super-regeneration. The fact that the suprascapula was apparently not disturbed during the operation 1s evidence of 1ts extreme dorsal and deeply Imbedied locetion. 
Table 8

Case $\frac{1}{2}$ VE 5

\begin{tabular}{ll|ll}
\hline \multicolumn{2}{c|}{ Regenerated G1rdle } & \multicolumn{1}{|c}{ Normal alrdle } \\
\hline Suprascapula & $640 \mathrm{mlcrons}$ & Suprascapula & $660 \mathrm{mlcrons}$ \\
Scapula & $390 \mathrm{mlcrons}$ & Scapula & $380 \mathrm{mlcrons}$ \\
Procoracold & $510 \mathrm{mlcrons}$ & Proooracold & $470 \mathrm{mlcrons}$ \\
Coracold & $830 \mathrm{mlcrons}$ & Coracold & $770 \mathrm{~m} 1 \mathrm{crons}$
\end{tabular}

The regenerated girdle in the absence of the free limb is incomplete in overy respect except for the suprascapula (f1g. 6). The anteroposterior length of the regenerated girdle is 770 microns as compared to the normal of 640 microns. The two parts of the ventral portion of the girdle appear rudimentary and are not joined together. The scapula and glonoid fossa are missing. Three other cases of this rentral series were sectioned. Four other cases were dissected, the g1rale and free limb in the latter cases being removed in toto (fig. 7). Results in all cases studied agree in general with the above conclusions, namely, that in cases in which the limb falled to regenerate, the girale 18 incomplete and usualiy in 
separate parts, especially because of the absence of the scapula. In cases in which the limb regenorated, the girdle was found to have regenerated as an essentially complete structure.

3. Removal of the postertor helf of the coreIImb rudiment (Ser1es PE). The exc1sed posterior half of the limb rudiment consisted of the area $a-b \times 1-3(f 1 g .1)$. The orthotop1c site was cleaned of any 10080 cells, especielly under the pronephric tubules, whlch were also removed with the graft. Animals in this serios wero at stage 34 . A slight movement was noted during some of the operations, although none of these animels wes anesthetized. Only two of these animala regenerated limbs. In the case rigured the regenerated limb was rudimentary, the radius and ulna woro fused, and no digits were present. The girdle In this case was essentially complete in all dimenatons (fig. 8). Romoval of the posterlor half usually suppressed development of the external free $11 \mathrm{mb}$, and in no case did these regenerate a completely normal free limb. Regenerated glrdies were morphologically complete in this exclsed posterior serles, even when there was not a free limb regenerated (fIga. 8-10). Grafted girdles obtained in this series were incomplete, as 
w111 be discussed later. In a case in whlch the IImb fallod to regenerate, it was found that all parts of the regenerated gircle were complete, incluring the glenold cossa in whioh a rudimentary fragment of the humerue has developed, although there was no appearanoe of a regenerated l1mb externalig (f1g. II A). Simllar rosulto were obtained from a study of four other cases. Measurements of a typloal case in which there was no visible froo $11 \mathrm{mb}$ are given in table 3 .

Tablo 3

\section{Caso 克 PE 3}

\begin{tabular}{|c|c|c|c|}
\hline \multicolumn{2}{|c|}{ Regenerated Girdle } & \multicolumn{2}{|c|}{ Normal atrdio } \\
\hline Suprascapula & 840 mlarons & Suprascapula & 550 micron: \\
\hline Scapula & $620 \mathrm{mlcrons}$ & Scapula & 530 miorone \\
\hline Proooracola & 720 mierona & Procoracola & 700 micron: \\
\hline Coracold & 820 mlcrons & Coracold & 920 mlerons \\
\hline
\end{tabular}

The coracold and glenold fossa are slightly saller than the normal. Limbs in these experiments falled to develop as in the dorsal and ventral ser1es, although girdle formation 18 much more complete. These girdles vere hypertrophled as anteroposterior mossurements indicate. 
Since a nearly perfect girdle was obtained In every case in which the posterior half of the disc was exc1sed, with or without the presence of limb regeneration, it is evident that very little girdie-forming material is located in this portion of the $11 \mathrm{mb}$ bud.

4. Remorel of the antertior half of the foreIimb rudiment (Sories $\frac{1}{2} A E$ ). This anterior half consisted of the area b-c $\times 1-3$ (F1g. 1). Animals used in this series were of stages 34-35. Since the mortality rate was high, only four animals were avallable for study. These, however, were good specimens, having regenerated $11 \mathrm{mb}$ and grafted girdles. Wounds were cleaned of 10080 mesoderm and the same care was given these animals as in the previous experiments. The mesoderm of these older embryos was tough and aticky. Wounds did not heal as readily as those of stages 29-32.

There is remarkable similarity among regenorated glrdies of this serles and those of the dorsal and ventral series. Here again the ventral portions of the orthotoplo girdle appear in two separate parts and are not articulated with each other or with the dorsal part of the girdlo. alrdie which developed In the absence of a freo-limb consist of the supra- 
scapula, rudimentary coracold and a procoracola (f1g. $12 \mathrm{~A}$ ). Girdles regenerated with a free limb exhibit similar parts and in addition a rudimentary glonold cavity which did not appear in tho above mentioned girdle ( 1 Ig. $13 \mathrm{~A}$ ). Anteroposterlor measurements of the latter case are given in table 4.

Table 4

Case 눌 AE 6

\begin{tabular}{ll|ll}
\hline \multicolumn{2}{c|}{ Regenerated alrdle } & \multicolumn{2}{c}{ Normal alrdle } \\
\hline Suprascapula & 580 mlcrons & Suprascapula & 470 mlorons \\
Scapula & None & Scapula & 260 microns \\
Procoracola & 290 microns & Procoracold & 320 mlorons \\
Coracold & 970 microns & Coracold & 1160 mlerons
\end{tabular}

since in this series the suprascapula only is consistently present in the regenerated girdie, it 1s obvious that cells which form the suprascapula are not contained in the excloed anterlor half of the $11 \mathrm{mb}$ bud. As the scapula does not appear at all in this series, cells which form this portion of the girdle are apparentiy contained in the anterior half of the limb disc. The Imperfect condition and reduced size of the coracold and procoracold Indloate that these parts are also located 
at least partially in the anterior half of the disc. In these experiment girdle formation seems to be Independent of the presence or absence of the free $11 \mathrm{mb}$.

\section{B. arafts}

The exolsed portion of the right 11mb bud was grafted on the right flank of the same animal, all graft therefore being autoplaat1e, homoploural, and heterotopic. The 1ze, shape, and location of the ext1rpated rudiments have been described prev1ously (p. 8). Wounds somewhat larger than the excised portion of the limb bud were first prepared on the right flank of the animal and the exc1sed portion of the IImb bud was superimposed over the exposed mesoderm. All grafts were of normal orlentation. Most of the grafts woro completely healed in from twelve to twenty-four hours.

1. Pranglantation of the dorsal half of the I1mb bud (Series $D G$ ). The area of t1soue transplanted in these experiments is shown in $\mathrm{fig} .1$, as a-c $\times$ 1-2. The graft included part of the pronephros in order to obtain all the underlying mesoderm.

In two such transplants out of nine, the tissue was resorbed and no trace of a girdle was found 
Table 6

Showing results of traneplants

\begin{tabular}{|c|c|c|c|c|c|}
\hline Ser1es & $\begin{array}{l}\text { Total } \\
\text { exp. }\end{array}$ & Lived & $\begin{array}{l}\text { Orafts } \\
\text { Present }\end{array}$ & $\begin{array}{l}\text { Grafts } \\
\text { Resorbed }\end{array}$ & $\begin{array}{l}\text { Re-dupl1- } \\
\text { cat lons }\end{array}$ \\
\hline$\forall D O$ & 10 & 9 & 7 & 2 & 0 \\
\hline 竞 vo & 10 & 9 & 4 & 5 & 2 \\
\hline$\frac{2}{B} \mathrm{PO}$ & 10 & 7 & 5 & 2 & 0 \\
\hline$\frac{2}{8}$ & 6 & 4 & 3 & 1 & 0 \\
\hline
\end{tabular}


(table 5). The other seven developed 1nto $21 m b s$ whlch were more or loss abnormal. Most of these Ilmbs were curved and atroph1ed; all lacked function.

The grafted girdle 1s rudimentary, consisting of an escentially complete copula and glenold fosse (fig. $4 \mathrm{C}$ ). The ventral portion of the coraco1d 1s missing.

Table 6

Anteroposterior meamurements $\frac{1}{8}$ DO 10

\begin{tabular}{|c|c|c|c|}
\hline \multicolumn{2}{|c|}{ Oraft $(1 \mathrm{~g}, 4 \mathrm{C})$} & \multicolumn{2}{|c|}{ Hormal $(F 18 \cdot 4 \mathrm{~B})$} \\
\hline Soapula & 270 microns & Scapula & 450 miorons \\
\hline Coracoida & 530 mierons & Coracold & 780 microns \\
\hline
\end{tabular}

The suprascapula and procoracold are missing. The mid-portion of the girdle 1s well developed although somewhat reduced in size as shown in tablo 6 . These missing parts are to be found in the regenerated girdle, namely, the auprescapula, procoracold, and ventral portion of the coracold (f1g. 4 A). A comparison with the regenerated rudiment shows that a coracold has dęreloped in both. This might be explainod on the supposition that this rudiment was divided into two parts by the operation, one part being grafted to the now location and one part being left in 1ts 
original position.

The presence of the suprascapula in an orthotopic position soems to indicate that this rudiment 11e far dorsal on the rlank, apparentiy above the point of ext1rpation. The presence of procoracoid in the orthotopic position and its absence in tho graft is also very aignificant.

2. Trangolantation of the rentral half of the $11 \mathrm{mb}$ bud (Serlos $\mathrm{t}$ V). The aree of mesoderm transplanted in these experiment consisted of the area a-0 $\times 2-3$ (f1g. 1). All graft wero autoplast1c, homopleural and of normal orlentation. Four such transplants geve rise to deformed limbs, two of which showed reduplications of the ontire free $11 \mathrm{mb}$ (table 5). In the cases of the reduplications, single girdles wore found. The humerl were fused at tholr distal onds and artioulated in aingle glonold fossa. One animal died before significant development had occurred. The romalning five developed Imperfect graft whloh wore resorbed in from six to ten days.

Girdles which had developed in these exper1ments were composed of a central and ventral zone. These parts of the girdle are complete with respect to thoir elements, $\nabla 1 z$, scapula, procoracold, and 
coracold. In both cases of reduplicated limbs, each girdie contained a glenold fossa and a hypertrophled rudiment of the dorsal part of the coracold ( $118.5 \mathrm{C})$. alrdies found in these experiments were - imilar to those of the dorsal series, that 18, the suprascapula 1s missing entirely.

\section{Table 7}

Anteroposterior messurements $\frac{1}{2}$ VQ 2

\begin{tabular}{|c|c|c|}
\hline Grafted g1rc & ale $(f 1 g \cdot 5 c)$ & Normal g1rdle (P1g. 5B) \\
\hline Scapula & 470 micron & 270 microns \\
\hline Procoracold & 70 miorons & Procoraco1d \\
\hline Coracold & $620 \mathrm{microns}$ & 2360 m1crons \\
\hline
\end{tabular}

The scapula 18 apparently complete although somowhat hypertrophled. The glenold fossa and humerus (f1g. 6 C) eppear much the same as in the normal. The coracold 18 essentially complete, although its anteroposterior measurement is about half that of the normal (table 7). The two parts of the girdle, scapula and coracold, form a single plece of cart1lage, but they are connected by only a narrow zone of Junction. A deep glenold fossa hes formed. 
of the regenerated girdle, it is cound that the Grafted girdle 1s composed of a morphologically perfect scapula and coracold; the former is missing entirely in the orthotopio position while the latter 1. represented by en extrome ventrel rudiment. The procoracold is found in both the grafted and the regenerated girdle. The procoracold is situated in the mld line of the girdie.

Ext1rpating the dorsal or ventral half of the $11 \mathrm{mb}$ disc, it would be expected that portion of the procoracold would be included in the extirpation and part would remain undsturbed in the orthotopic position. In the same way the extirpation did not include the extreme doral rudiment of the coracold, hence, this portion developed in 1ts orlgInal place. The entire scapula was included in these grafts, and therefore no rudiment of this scapula was to be found in the regenerated girdie. It is apparent that the suprascapula, due to 1ts extreme dorsal location, would be absent in these grafts.

In three cases the traneplanted girdles were stained in toto and alsected out. The results in general agreed with the case described in detail above. 
3. Pranaplantation of the postorior half of

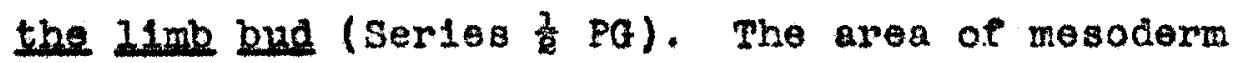
trinsplanted in these experiments consisted of the area $a-b \times 1-3$ (fIg. 1). In two cases out of ten the graft was resorbed after five days, and no traces of girdles were to be found. Three animals died shortly after the operation and wore lost to the experiment (table 5). The other five developed limbs, all of which had abnormal hands. The forearm and hand of these grafted $11 \mathrm{mb}$ were especielly deformed. All limbs lacked Punction.

olrdies which developed in these experiments were rudimentary as compared wh th those formed in the other three series, yet a high percentage of free limbs were obtained. Those grafted girdios were composed solely of the glenold portion of the coracold, other parts of the girdle being entirely misaing. In $118.10 \mathrm{C}$, the girdle is represented by audimentary coracold with well-formed glenold fossa. In the case $\frac{1}{8} \mathrm{PO} B(\mathrm{flg}, 11 \mathrm{c}$ ) the girale appears in two parts as dorsal and ventral rudiments, presumably both belng parts of the coracold. These parts are not jolned at anj place. The anteroposterior length of these two pieces of cartilage 18 250 microns, a small rudiment as compared to 950 
mierons of the normal coracold and 1020 microns of the same structure of the regenerated gIrdio. Although the glenold fosse of the grafted girdle was very poorly developed in this osse, in other cases (as 㺼 $P Q 3,11 g .10$ ) 1t was woll formed. Regenerated glrdies were completely formed except for poorly developed glenold fossa.

The five transplants wh1ch developed graft: were found to possess complete external limbs but rudimentary girdies. A comparison of the grafted girdlo rudiment with the orthotopic one shows cleariy that these two parts combined would approximate a complete glrdie. Th1s shows that the suprascapula, scapula, and procoracold portions of the girdle are not present in the posterior portion of the $11 \mathrm{mb}$ disc, but that abundant $11 \mathrm{mb}$-forming cells are. A small part of the girdle rudiment was contalned in the transplant along with limb-forming cells. The $11 \mathrm{mb}$ is an equipotent1al system as stated by Harrison (18); therefore complete 11mb were usually obtalned. since only a small rudiment of the pectoral g1rdie appeared in the transplants, further evidence 1s obtalned that it is a mosalc oystem. Detwiler's thesis, that whon a portion of a rudiment is removed there appears a deflclency at that location and when a portion of a rudiment is transplanted only that 
portion develops, is substantiated by these find1nge.

4. Iransplantation of the anter1or half of the limb bud (Serles $\frac{1}{2} A O$ ). The area transplanted In these experiments is shown in $11 \mathrm{~g} .1$, as b-c $\times 1-3$. S1x animal were used, two of which gave rise to deformed IImbs. Each of these animal regenerated complete free $11 \mathrm{mb}$ and girdles as well. In the case of $\frac{1}{2}$ AO I a complete grafted suprascapula was found In the region of the graft. The remaining ombryos developed Iimb budiment that were resorbed from four to six days after the operation. Several days later these embryos died and were lost to the experiment (table 5 ).

The grafted girdies of thls serles are quite simllar to those of the dorsal and ventral series. Two an1mals were studied, each possessing grafted 11mb. The girdies were 1dentical, consisting of a well developed soapula, procoracold, glenold fossa, and coracold. No part of a suprasoapula was to be found (11g8, 12-13).

The measurements show the vontral half of the grafted girdle to be complete (table 8). The ventral portion of the grafted coracold appears blunt In the case of each animal studied. 
Table 8

Anteroposter for measurement s $\frac{1}{2}$ AO 6

\begin{tabular}{ll|ll}
\hline Orafted girdle (fig. lOC) & Normal girdle (f1g. 1OB) \\
\hline Scapula & 290 microns & Scapula & 250 microns \\
Procoracold & 210 microns & Procoracold & 420 microns \\
Coracold & 730 microns & Coracold & 730 microns
\end{tabular}

The most ventral part of the coracold of these girdles appears in the orthotopic position. It then seems 11kely (f1gs. 12-13) that the ventral part of the coracold was not included in the transplants. A small portion of the procoracold also appears in the regenerated girdle. The scapula and glenold part of the girdle are complete in the graft but entirely missing among the regenerated parts of the girdle.

Results of these experiments indicate that the parts of the grafted girdle would supplement those of the regenerated girdie to form a complete girdle. Girdle formation seems to be independent of the presence or absence of the free 11mb, as has been demonstrated in previous experiments. The anterior half of the girdle rudiment was transplanted with the anterior part of the limb rudiment. A limb 
develops from the transplanted rudiment of the limb anlage but only that portion of the girdle develops which has boen transplanted. Again these result agree with those of Detw1ler (118) that the pectoral girdlo of Amblystome is a mosalc.

In the case of $\frac{1}{8} A G 1$, which was stained in toto, no part of the graft ( $11 \mathrm{mb}$ or girdie) was visible externally. In the region of the graft a complete supracapula could be seen after removal of the skin. This rudimentary girdle had no attachment and no other girdle part were to be found. The regenerated girdle and $11 \mathrm{mb}$ of this specimen were complete, although the distal end of the suprasoapula appears to be blunt. The suprascapula, a provlously noted, 1108 so far dorsal that it was included in only this one transplant. Since thio animal possessed such a perfectly regenerated limb and girde, it is possible that the graft included only a small portion of the rudiment of the suprascapula (f1g. 14). 


\section{v. GENERAL DISCUSSION}

In all four serles of experiments at least partial girdles developed in the absence of a free 11mb. Particularly when the posterlor half of the $11 m b$ bud was extirpated, complete orthotople girdles developed in the absence of the free 1imb. This is In agreement with Detwiler $(118)$ and swett and Parsons (129) who obtained conclusive results showling that the pectorel girdie develops independently of the free 11mb. However, in the present experiments in the doreal and ventral series girdles which developed in the presence of the free limb were more nearly complete than were girdes obtained in the absence of the free limb, showing that the girdles have some power to regenerate lost parts. Orthotopic and grafted girdies in the dorar and ventrel serles seem to supplement each other, as has been shown in this paper. The supposition that the posterior portion of the $11 \mathrm{mb}$ alsc contains limb-forming cells would explain the absence of the free limb in the orthotopic position and the very rudimentary girdie in the heterotopic position. In the dorsal and ventral serles the orthotopic 
girdle seemed more complete when the free limb developed along with the girdie. In one case ( $\frac{1}{2}$ VE 5) a super-regeneration of the orthotop1c girdle took place. All the parts of the girdle had not only regenerated, but the scapula and suprasoapula were much thicker than in the control girdie. The grafted girdle in this case conslsted of a rudimentary coraoold which was abnormally thick. When the posterior half was extirpated, morphologically complete girdies were obtalned from the portion remainling oven in the absence of the free 11mb. In two of the cases studied, orthotople girdies were practically 1dent1cal with the normal. A small diatel ond of the humerus was also found in each of these cases. As hes been stated before, the posterior portion of the limb disc contains practically no girdlo-forming elements, honoe the girdle would not be greatly disturbed as results hereln indicate. Schwind (132) reports in his findings on the torsion of the forelimb that the entire girdle rudiment of the embryo (A. punctatum) 110 s anterior to a line formed by the projection of the fourth-fifth somite boundary. arafted girdles in this serles were very rudimentary, although freo limb accompanied these rudiments. Here 21so, only these ports of the rudiments which were 
trensplanted at the time of the operation developed from the grafts.

Cases studied in the anterior series present quite similar results, in that only the primordial segregates of the girdle which were included in the transplant doveloped. The remainder of the Birdlo was left in 1ts original location and developed a 1solated cart1laginous fragments.

In no case was the suprascapula absent in the normal position. Detwiler (118) has reported that the suprascapula in A. punctatum dovelops from a separate rudiment of lts own. Results in all these experiment on A. microatomum bear out his findings. He also reported that the ouprascapula lles far dor$8 a l$ and deeply 1mbedded so that exc1sed parts of the Iimb afsc, in order to contain the suprascapula, would nocessar1ly cover a larger area and contaln more deeply Imbedded mesoderm. Swett and Parsons (129), after removal of the whole girdle in A. punctatum at older stages, found defiolencies in all cases in the most outlying parts of the regenerated girdle, namely, the suprascapula and procoracold. In one case only ( $\mathrm{A}$ AB 1, 11g. $14 \mathrm{C})$ has a suprascapula been found in a heterotopic location. This grafted suprascapula was the only segregate of the girdle to differentiate and can perhaps be ex- 
plained in this way. The exclsed portion may have Included tisaue dorsal to the limb disc, but only the most anterior part of the 11mb alsc proper.

The procoracold develop later than the other parts of the girdie. It $1 \mathrm{~s}$ mall in larvae at the age sectioned, but could be recognized. Swett ('296) In extirpating the procoraco1d (A. punctatum) found this segregate to be very emall at stage 46 . However, It seemed to be quite a distinct rudiment in A. microstomum since it was often left behind in the orthotop10 position where it appearod a separate plece of cart1lage.

Development of a heterotoplc scapula was obtained in all series of experiments except the posterior ser1es. All resulte indicate that if the scapula 1s transplanted, development of this structure takes place in the graft and 1o entirely missing in the orthotopio position; not the slightest tendency of any restitution process was to be found in the case of this ossifying structure. The soapula was ontirely absent in the graft from the posterior half of the limb disc, but fully dereloped in the orthotople girale. This agrees with our previous hypothesis that the posterior half of the limb dise contalns largely limb-forming mesoderm, and that girdle-forming 
mosoderm is prosent in extromely small amount. The development of a rudimentary coracold in every case in both the orthotop1c and hoterotop1c positions is ovidence that a part was transplanted and a part left undisturbed. Rosults in all cases studied ahow that orthotop1c and heterotopic rudiment of the coracold are largely supplementary. The fact that rudiment of the coracold appeared in both the orthotople girdies and in the grafts, and that these parts are aupplementary may bo ev1dence of at least two distinct sogregates for this structure, More experiments would be necessary to prove this hypothesis.

There appears to be slight restitution on the part of the coracold. In cases where the major part of the coracold was present, whether in the orthotopic girdle or graft, it underwent some rest1tution, especialiy by forming narrow strip of cart1lage ventrally.

Detwiler (118) on A. punctatum has shown that operations used in ext1rpating the $11 \mathrm{mb}$ rudiment Leave parts of the procoracold and coracold in the ombryo. By process of hyperplasia these cartilages gradually extend across the gap between them unt11 they become united into a girdle which is topograph1cally complete. This tendeney of the coracold to 
undergo some restitution therefore bears out the roaults of Detwiler.

From the above results it is apparent that the pectoral girdle of $\underline{A}$. mlerostamum is mosalc and consiats of at least four diatinet primordia. It has, however, a strong tendency to regenerate missing parts in cases where the free limb regenerated.

Detw1ler (118) reports that by remoral of the dorsal half of the limb bud together w1th the third, fourth, and fifth myotomes he wa able to suppress development of the suprascapula, scapula, and the free limb so that only the ventral half of the glrdle develops, whereas rowults in thls paper show that removal of the dorsal half of the $11 \mathrm{mb}$ alsc but not the myotomes has little or no effect on the suprascapula, but that development of the soapula and glenold portion is suppressed, as well as devolopment of the froe 11mb. Detwller found that heterotopic girdles, which developed from the dorsal transplants, consisted of a dorsal zone: the suprasoapula, scapula, and the dorsal part of the coracold. Results in this papor show complete scapula, dorsal portion of the coracold but not nearly as much of the auprascapula as is shown by Detwller, 
probably because the myotomes dorsal to the limb disc were not included in the transplant. The fallure of the cells of elther the ventral or dorsal zones to regenerate the missing zone indicates thoir lack of equipotentiality.

After removal of the pectoral girdle and the $11 \mathrm{mb}$ of A. punctatum at older stages (atage 46), Swett and Parsons (129) supposed that a small bar of cartilage found just lateral to the pronephros was fragment of the suprascapula which was not removed at the time of the operation. It is reasonable to assume, from the similarity of results in this paper and those mentioned above, that cells lying so close to the pronephros were also not removed in our extirpation experiments. In this way the repeated absence of the auprasoapula in the grafted girdle and it consistent presence in the orthotopic position might be explained. They also reported that when they removed the girdle but not the freo limb, a complete girdie developod. M1croscoplc study showed that a blastema of mesodermal t1ssue formed which resembled the limb primordium In earlier atages and from this differentiated a complete girde.

In some cases Swett and Parsons (129) reported that secondary limbs grew, finally fusing with the 
primary I1mb at the distal end of the humerus. Regenerated girdles in these cases were single girdles. In the present study imilar results were obtained when the ventral half of the $21 \mathrm{mb}$ disc was removed, namely, a single girdie associated with pair of Iimbs. It is obvious that these results of swett and Parsons (129) are in complete disagreoment with those of Detwller (118) who used the same species except at earlier atages, and of the reaults obtained in this paper. Apparently age of the larvae 18 the controlling factor.

When part of the girdle rudiment is removed at such an early stage that the regions of the girdle are at111 preprimordial segregates, the regeneration processes do not manifest themselves in regard to the poctoral girdle. Therefore, whenever one or more of the four segregates of the girdle-mosale 1 s removed then that portion w11l be misalng in the girdle which forms. This accounts for the partial girdles obtalned by both Detwiler and the writer. In these early stages a regeneration blastema of the kind reported by swett and Parsons falls to form. Healing is quick and complete and a result no regeneration of missing girdle rudiments occurs. 
1. The pectoral girdle of $\underline{A}$. microstomum w11l develop in the presence or absence of the free limb although 1ts power of restitution seems greater when the $11 \mathrm{mb} 1 \mathrm{~s}$ present.

2. The embryonic shoulder-girdie is a mosale composed of at least four primordial segregates in the tall-bud stage.

3. Each primordium develops independently in both orthotopic and heterotopic positions.

4. The posterior half of the 11mb-d1sc contains an abundance of 1lmb-forming cells and very little girdle-forming t1ssue.

5. The procoracold develops so late that it 1s rery small in comparison to other girdlo structures at stages studied in this peper.

6. The primordium of the suprascapula 1s located dorsal to the limb-d1sc, or dorsal to areas extirpated in the experiments reported here.

7. In cases in which the graft roduplicated, only a single shoulder-girdle was found. 
Detwiler, S. R. 2918 Experiments on the derelopment of the shoulder-girdie and the anterior I1mb of Amblystoma punctatum. Jour. Exp. Z0ol., vol. 25, pp. 499-537.

Franc18, Er10 T. B. 1934 The Anatomy of the Salamander. Oxford Jniversity Press, Oxford, pp. 37-39.

Harr1son, R. Q. 1918 Experiments on the development of the fore-11mb of Amblistoma, a self-differentiating equipotent1al system. Jour. Exp. Zool,, vol, 25, pp. 413-461.

Noble, K. G. 1931 Blology of the Amphibla. MoGraw\#11 B Book Co., New York, pp. 234-287.

Parsons, E. H. 1928 studies on the houlder-girdle of Amb2yatoma punotatum (IInn). V. Regeneration of the cartilaginous girdle in heterotopic position. Jour. Exp. Zool., vol. 54, pp. 23-30. 
Schw1nd, J. L. 1932 Further experiment on the $11 \mathrm{mb}$ and shoulder-81rdie of Amblyatome. Jour. Exp. Z001., vol. 63, pp. 345-363.

Stultz, W. A. 1936 Rolations of symmetry in the hind $1 \mathrm{imb}$ of Amblyatome punctatum. Jour. Exp. Zool,, vol, 72, pp. 317-367.

Swett, F. H. 1823 The prospective significance of the cells contained in the four quadrant of the primitive $11 \mathrm{mb}$ disc in Amblyetome. Jour. Exp. Zool., vol. 37, pp. 200-217.

Swett, F. H. 1829a studies on the shouldergirdle of Amblystoma punctatum (LInn). IV. The results of grafting the cart1laginous girdle. Jour. Exp. Zool., vol. 54, pp. 1-21.

Swett, F. H. 1929b Studies on the shouldergirale of Amblystome punctatum (Linn). III. Regeneration of the cartilaginous girdle after Its partial removal. Jour. Exp, Z001, vol, 53, pp, 35-44. 
Swett, F. H. and Parsons, E. H. 1829 Studies on the houlder-girdle of Amblystoma punetatum (IInn). II. Regeneration of the cart1laginous girdle after its complete removal. Jour. Exp. Zool., vol. 53, pp. 13-25. 
VIII. FIGURES

\section{Abbreviations}

$\begin{array}{llll}\text { cor, coracold } & r . u, & \text { radius, ulna } \\ \text { hum, humerus } & \text { s.sc, suprascapula } \\ \text { p.cor, procoracold } & \text { r }, \text { rogenerated glrdle } \\ \text { sc, scapula } & \text { n }, \text { control left girdle }\end{array}$


P1g. 3 Camera-luolda drawlings of case $\mathrm{DE} 1$. $x$ 40. A, orthotop10 girdlo developed after removal of the dorsal half of the limb bud, the free limb having regenerated. B, 18 control left girdle. The graft was resorbed.

F1g. 4 Camera-lucida drawings of case $\frac{1}{8}$ DE 10. $x$ 40. A, orthotopio girdle developed after removal of the dorsal half of the $11 \mathrm{mb}$ bud, the free $11 \mathrm{mb}$ having falled to regenerate. B, control left girdlo. C. section of transplant. 


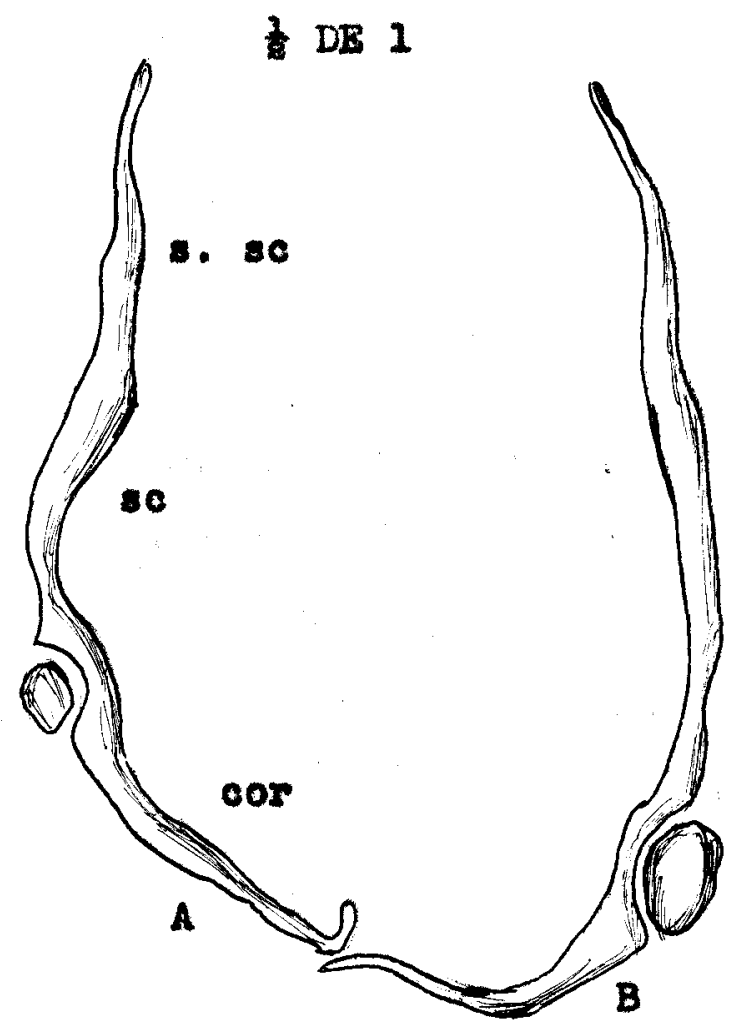

F18. 3

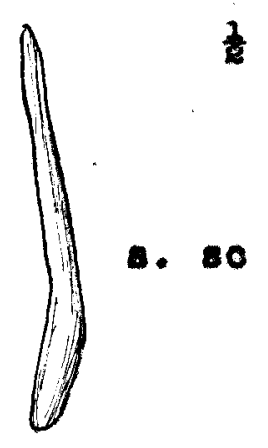

DE 10
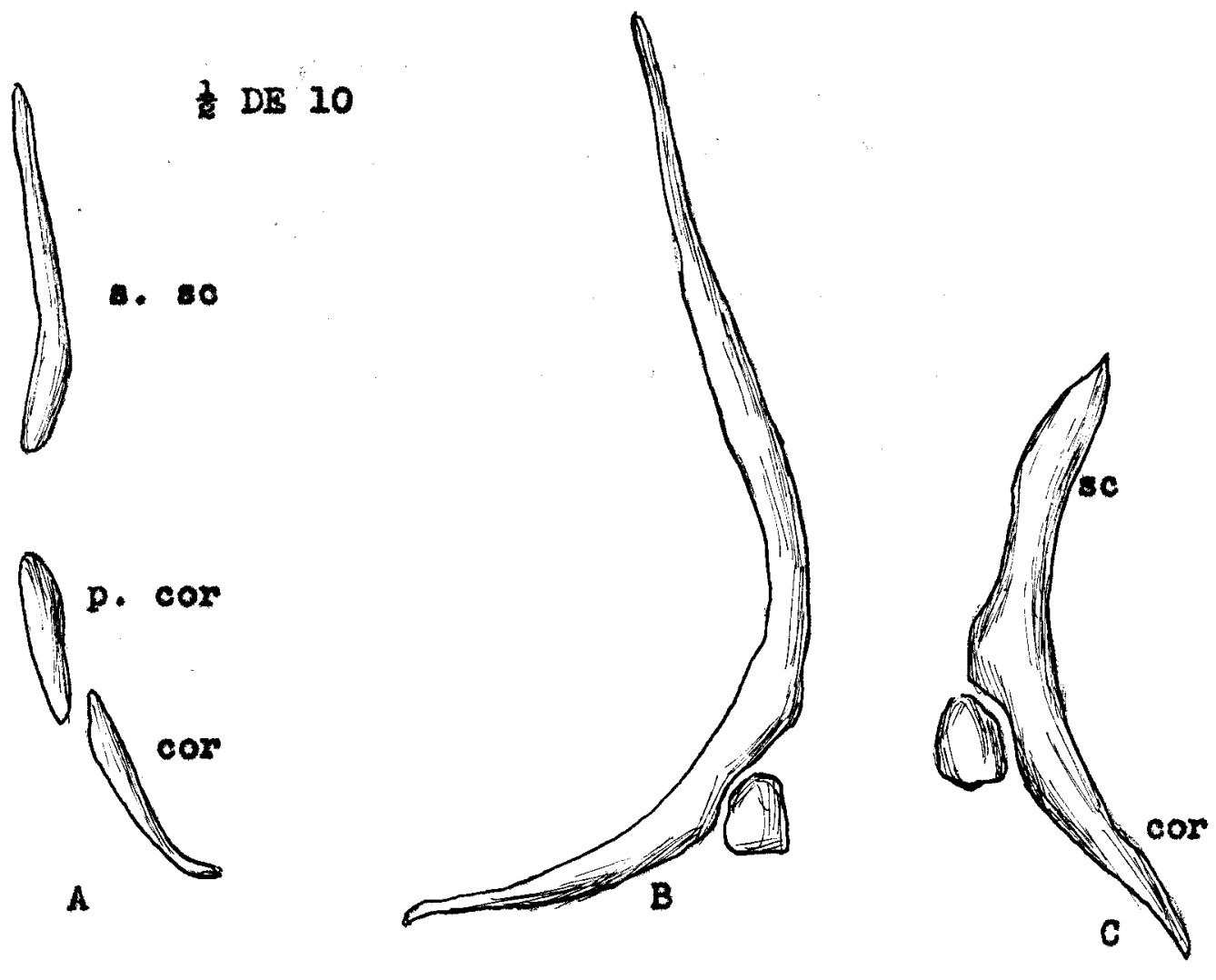

P1g. 4 
F1g. 5 Camera-1ucida drawings of case $\frac{1}{8}$ VE 5 . $x$ 40. A, orthotopic girdle developed after removal of the ventral half of the $11 \mathrm{mb}$, the free $11 \mathrm{mb}$ having regenerated. B, control left girdie. C, section of transplant.

P1g. 6 Camera-1ucida drawings of case $\frac{7}{8}$ VE 2 . $x$ 40. A, orthotop1c girdle developed after removal of the ventral half of the $11 \mathrm{mb}$ bud, the free $11 \mathrm{mb}$ having falled to segenerate. B, control left girdle. C. section of transplant. 

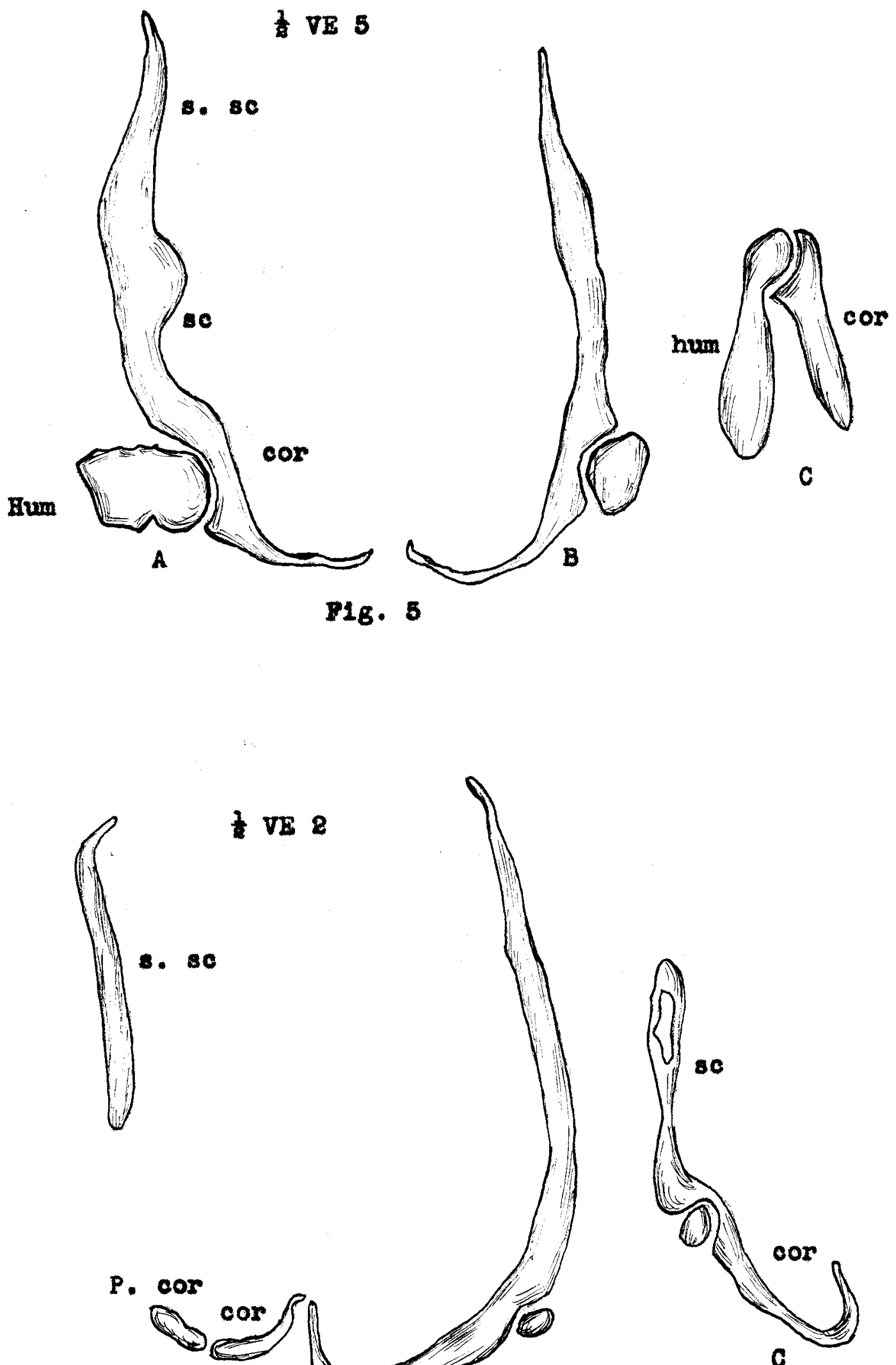
A (

P18. 6 
P1g. 7 Camera-lucida drawing of the regenerated g1rdie and free $11 \mathrm{mb}$, case $\mathrm{VE} 8 . \times 40$. Vlewed from the mes1o-dorsal aspect; shaded portion of the girdie - ossifled. The graft in this case was resorbed. 


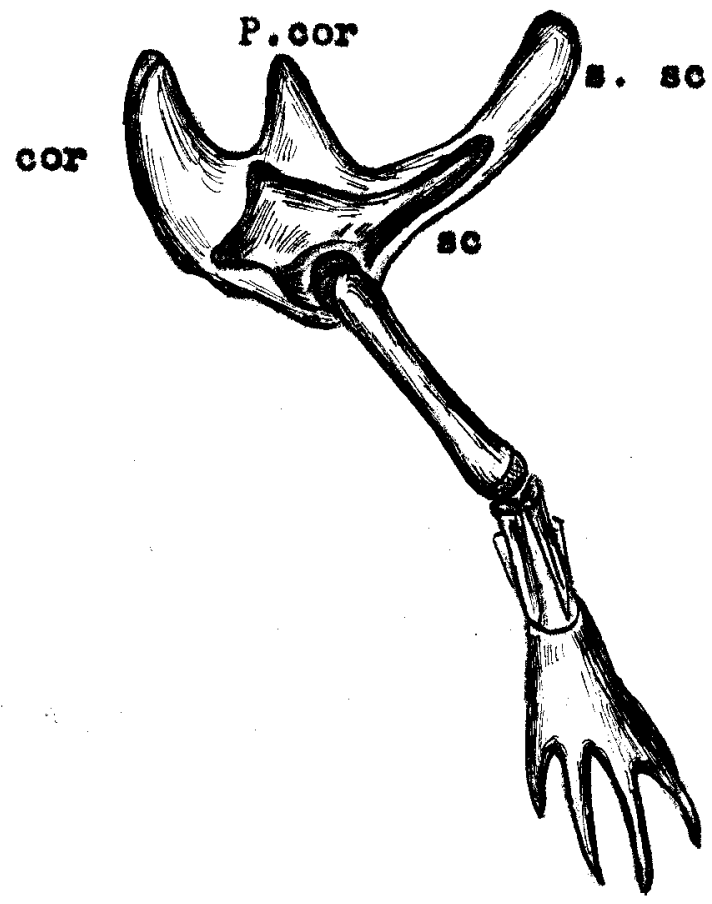

F18.7. 7 V 8 
P1g. 8 Camera-lucida drawings of the regenerated girdle and free limb, case $\mathrm{PE} 9 . \mathrm{x} 40$. A, vlowed from the mesio-dorsal sopect. B, viewed from the ventrolateral aspect. Heavy st1pplo show ossification. The graft in this case was resorbed. 


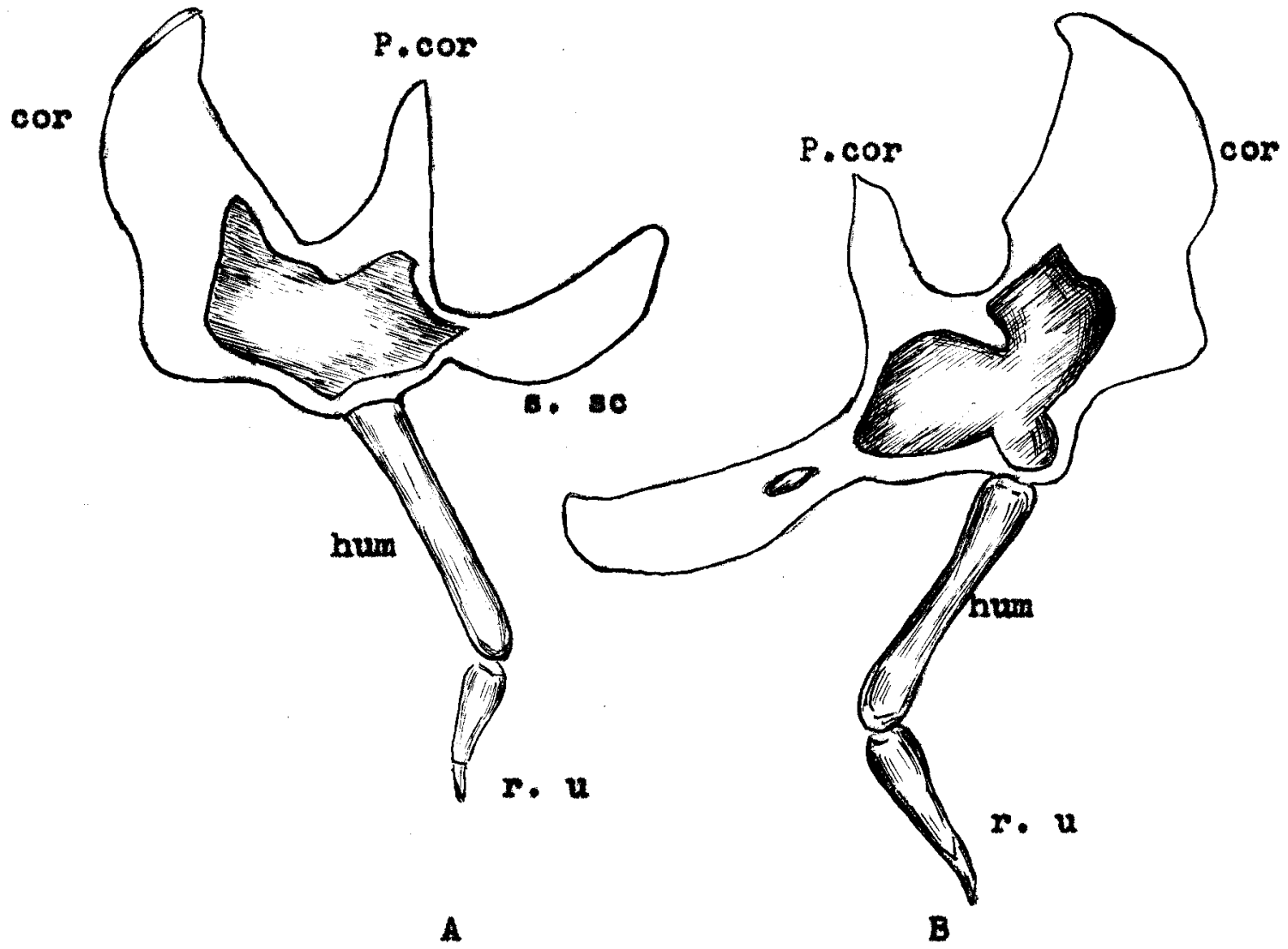

F1g. 8. 曹 PE 9 


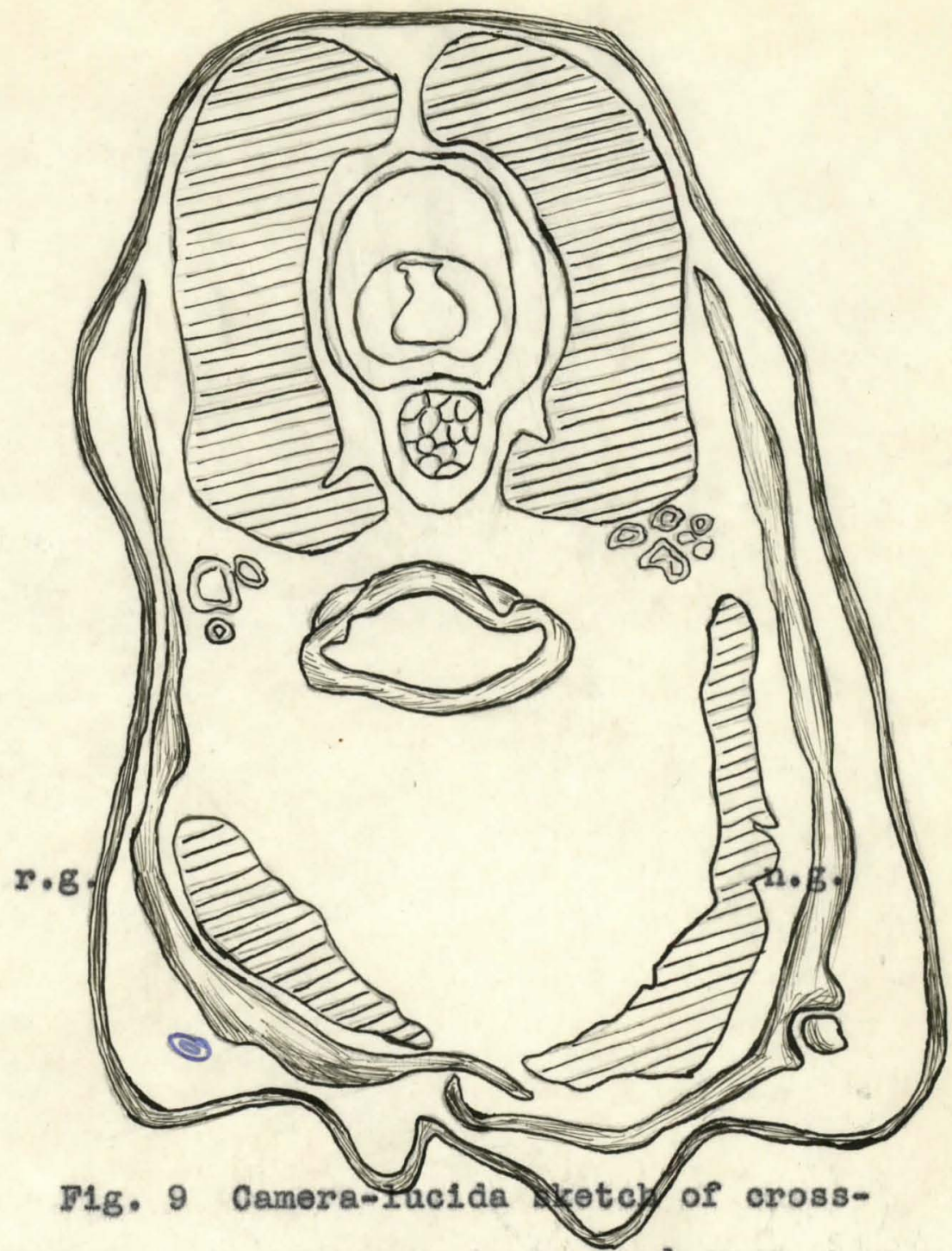

section of A. microstomum larva $\frac{1}{2}$ PE 3, passing through the region of the glenold fossa. Coarse st1pple, cart1lage; hatching, muscle masses. r.g. normal girdle, n.g., regenerated girdle. $x 40$. 
Fig. 10 Camera-lucida drawings of case $\frac{1}{2}$ PE 3. $x$ 40. A, orthotopic girdle developed after removal of the posterior half of the limb bud, the free limb having falled to regenerate. B, control left girdle. c, two adjacent sections of the transplants.

Pig. 11 Camera-lucida drawings of case 8 PE 8. $x$ 40. A, orthotop1c g1rdie developed after removal of the posterior half of the IImb bud, the free limb havling falled to regenerate, B, control left glrde. C. section of the transplant. 
58
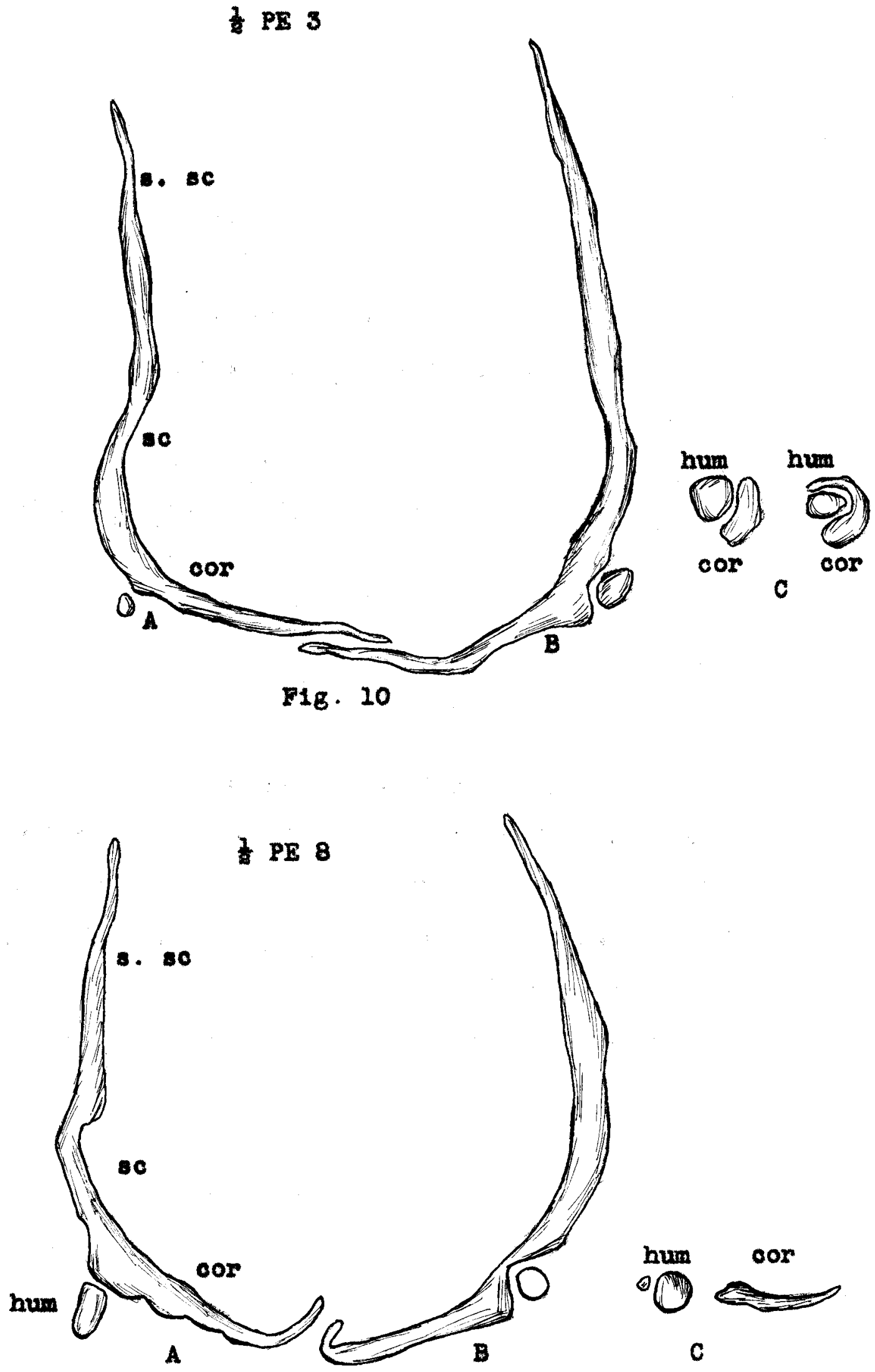

718. 11 
Fig. 12 Camera-lucida drawings of case $\frac{7}{2}$ AE 5 . $x$ 40. A, orthotople girdie developed after removal of the anterior half of the $11 \mathrm{mb}$ bud, the free limb having faliod to regenerate. $B$, control left giralo. C. section of transplant.

P1g. 13 Camera-1ucida drawings of case $\frac{7}{2}$ AE 6. $x$ 40. A, orthotop10 girdle developed after removal of the anterior half of the limb bud, the free limb having regenerated also. $B$, control left girdle. C. section of transplent. 


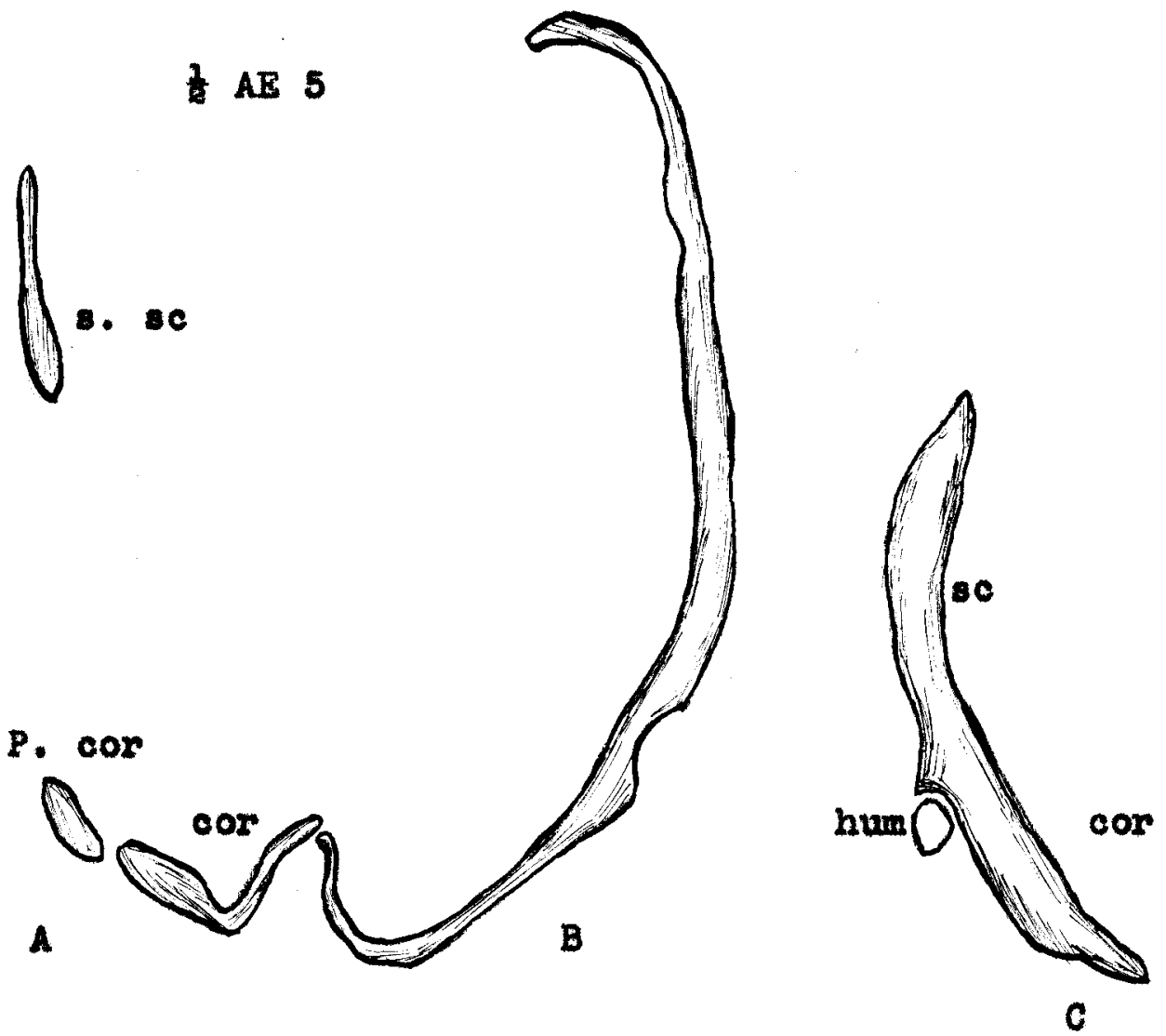

P1g. 12
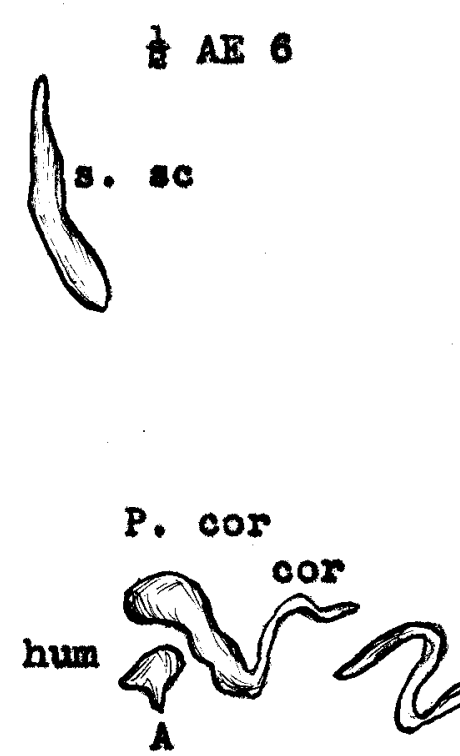

$B$

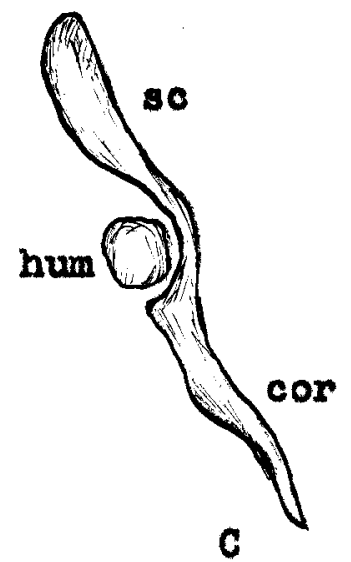

F1g. 13 
18. 14 Camera-luclda drawlings of the regenerated glrale, freo $1 \mathrm{mb}$, and graft, case $\frac{7}{2} \mathrm{AE} 1$. $x 40$, from the mesio-dorsal aspect. B, represents the ent1re traneplant. 


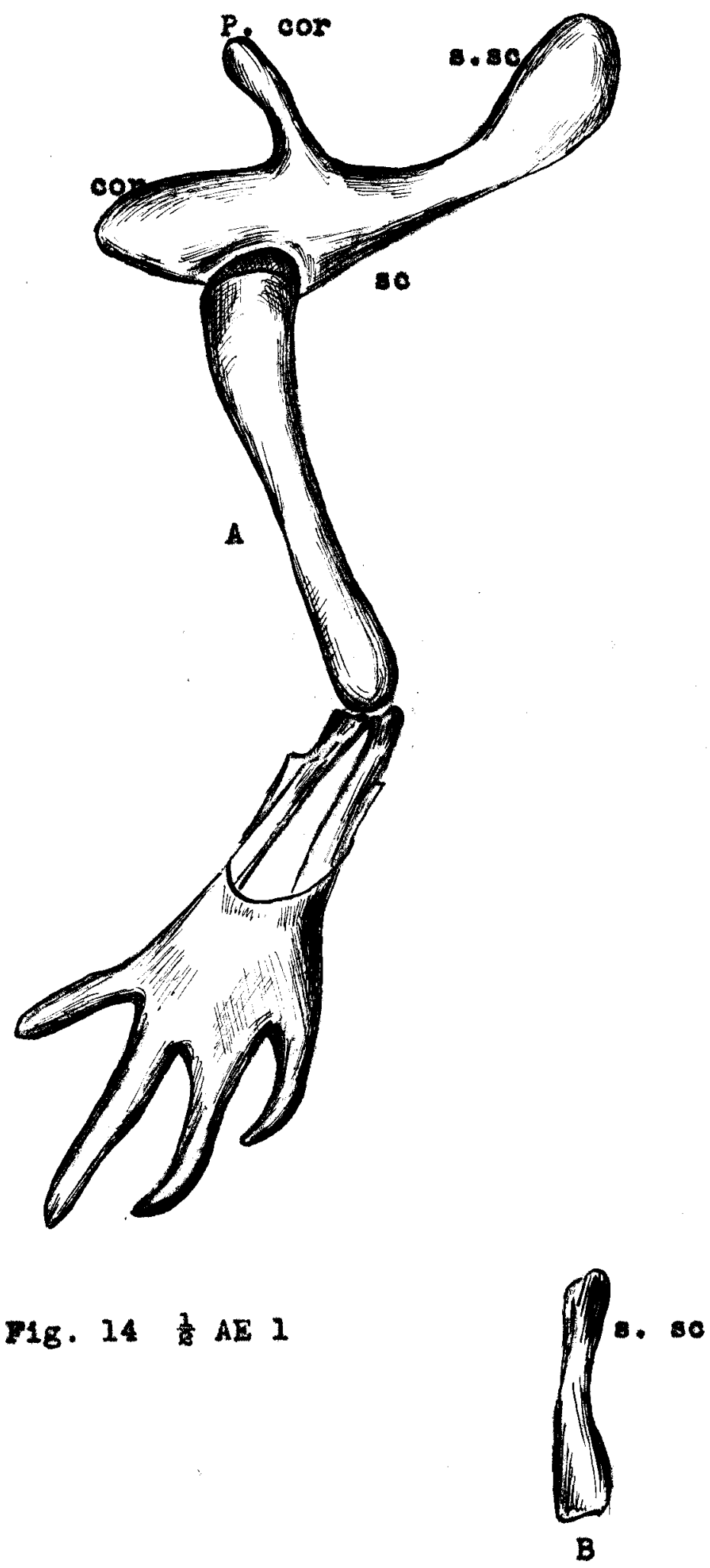

